\title{
DATING THE FIRST AUSTRALIANS
}

\author{
Richard Gillespie \\ Dizzy Heights, Ripps Road, Stokers Siding NSW 2484, Australia. Email: dizzy@ better.net.au.
}

\begin{abstract}
The dating of selected archaeological and megafaunal sites from the Australian region is reviewed, with emphasis on recent work at some of the oldest sites. Improved chemical procedures with decreased analytical background for ${ }^{14} \mathrm{C}$ analysis, combined with new luminescence dating methods, has confirmed many of the results processed decades ago and significantly increased the maximum age for some others. The oldest occupation horizons in four different regions reliably dated by defendable multi-method results are in the range $42-48,000$ calendar years ago, overlapping with the age range for similarly well-dated undisturbed sites containing the youngest extinct megafauna. There is less secure evidence suggesting some archaeology may be earlier and some megafauna may have survived later than this period.
\end{abstract}

\section{INTRODUCTION}

Estimates of the time since humans first occupied the extended Late Pleistocene continent Sahul (sometimes called Greater Australia or Meganesia) have steadily increased since systematic archaeological excavation and radiocarbon dating became established in the 1960s. Jones (1968) considered 30,000 BP a reasonable estimate for the earliest arrivals, based on the available evidence showing 3 or 4 sites with ${ }^{14} \mathrm{C}$ dates of more than 20,000 BP. In the second edition of The Prehistory of Australia (Mulvaney 1975) an appended date list documented four sites in Australia and one in New Guinea with ${ }^{14} \mathrm{C}$ results older than 25,000 BP. The current edition (Mulvaney and Kamminga 1999) provides an overview of the hundreds of dates now accumulated for Late Pleistocene archaeological sites in Sahul. Some of the robust debate about claims for earliest occupation of the region is presented in Murray (1998).

Traditional ${ }^{14} \mathrm{C}$ dating using radiometric counting has become less important in Sahul, as elsewhere, since accelerator mass spectrometry (AMS) laboratories began to take on large workloads from the mid 1980s. In many situations this new measurement technology also allowed better pretreatment chemistry to be applied in the isolation and decontamination of specific sample components. At about the same time newer thermoluminescence (TL), optically stimulated luminescence (OSL), electron spin resonance (ESR), amino acid racemization (AAR), and uranium-thorium series (U/Th) dating methods began to make significant contributions to archaeology and the earth sciences. These and other techniques operate under different rules and on different materials to ${ }^{14} \mathrm{C}$. An "archaeological event" such as a fire may sensibly be ${ }^{14} \mathrm{C}$ dated using charcoal, whereas luminescence methods on quartz sand are likely to be dating an "environmental event" such as exposure to sunlight, not necessarily directly associated with the target archaeological event. However, since everyone should eventually get the same answer to questions like "when did humans first colonize Australia" or "when did the megafauna become extinct" there are some instructive examples of cross-dating with different numerical methods.

Projects such as dating the first Australians or Americans have always been clouded by the bias brought to the debate by specialists from different academic fields. The physicists and chemists in dating laboratories argue about their measurements and what is being measured; archaeologists and geologists argue about associations between artifacts of human occupation and the sediments in which they are found. Dating specialists have a qualitatively different attitude to (and confidence in) their measurements compared with fieldworkers and theoreticians in other specialties. In a context of peopling the New Worlds, these related debates are all directed toward the establishment of an agreed time scale for human movements around the planet. The records we accumulate from excavations and numerical dating are necessarily discontinuous and incomplete, but there is now such a large dataset built in to the literature that deviations from established wisdom require stringent scrutiny. 


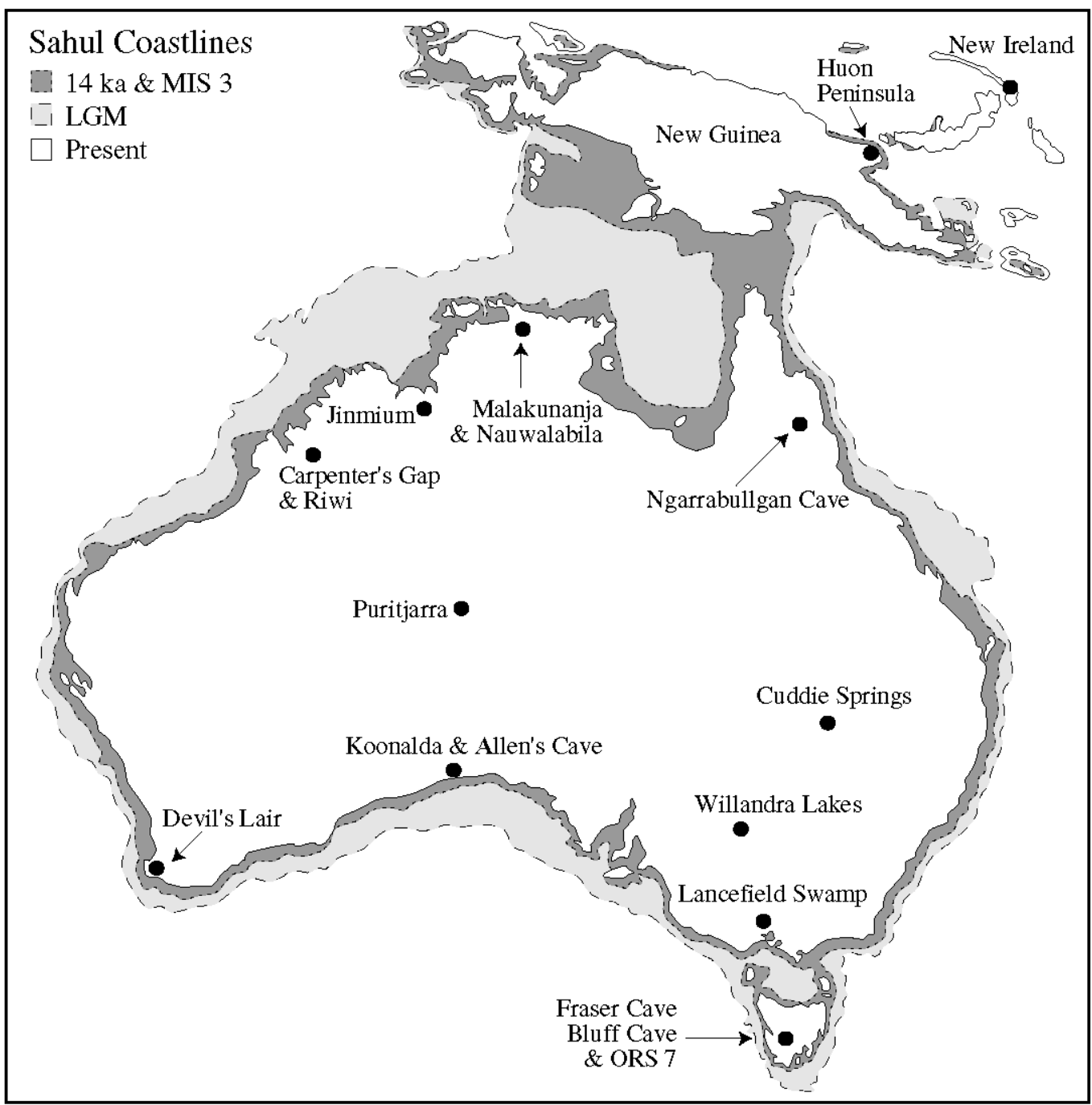

Figure 1 Map of the Australian region showing the location of sites discussed, with extended Sahul landmass at LGM (20-24 ka) and 14 ka (as proxy for Marine Isotope Stage 3), modified after Smith (1998).

A useful guide to the Australian debate is the concept of an "event horizon" (Chappell 1991), which places a maximum possible age limit on ${ }^{14} \mathrm{C}$ dates based on available technology and promotes calibration of the reported conventional ${ }^{14} \mathrm{C}$ ages. This idea is further developed to reconcile dating results over the 30 years since the "event horizon" for Australian archaeology was reported as $>37,800 \mathrm{BP}$, revealing strong similarities with archaeology and megafauna debates in Europe and the Americas.

\section{Geographical Background}

Getting to Australia has always involved sea crossings, because on timescales relevant to human evolution Sahul has always been an island continent. Assuming an African origin for modern Homo sapiens, the only human species known in the archaeological record of Sahul (Groves 1996), likely routes would have been eastward through what are now the islands of Indonesia in South East Asia. 
Throughout much of the Pleistocene, including the Last Glacial Maximum (LGM), the currently large islands of Australia, Tasmania, and New Guinea were linked by lowland plains. Reconstructions based on Huon Peninsula raised coral terraces and on marine cores from several regions show that during LGM sea level was about 120 meters below present (Chappell et al. 1996b; Shackleton 2000). Much attention has been given to the LGM period (20-25 ka) in relation to the peopling of Australia, because crossing from Southeast Asia (Sundaland) then would not have required as many (or as lengthy) sea voyages. Unlike the Americas, where first occupation appears to be a post-LGM event, it has been known for decades that the peopling of Australia began well before LGM.

It now seems probable that an extended Sahul continent existed not only at LGM but also throughout most of Marine Isotope Stage 3 (MIS3, 30-70 ka). Sea level fluctuated during MIS3 with decreasing amplitude in a range of about $60 \pm 20$ meters below present (Chappell et al. 1996b). Following LGM, sea level rose rapidly to reach a range similar to that in MIS3 by about $14 \mathrm{ka}$, shortly before Tasmania and New Guinea became isolated from Australia. The degree of difficulty for intrepid seafarers traveling from Asia to colonize Sahul would not have been significantly greater during MIS3 than at LGM, and there were no continental ice sheet barriers in Sahul to thwart enterprising explorers. These first arrivals in the eastern New World, making landfall possibly in northwestern New Guinea, would have been able to walk from the equator almost halfway to the south pole. Approximate coastlines for Sahul at LGM and at $14 \mathrm{ka}$ (as proxy for MIS3) are shown in Figure 1 (modified after Smith 1998), with the present geography and location of sites discussed here.

\section{${ }^{14} \mathrm{C}$ Results from Selected Archaeological Sites}

Only a few of the oldest well-documented archaeological sites in Sahul are considered, where recent work has begun to systematically refine the chronology of human occupation and the related topic of Late Pleistocene megafaunal extinction. The Holocene is mostly ignored to concentrate on Late Pleistocene sites with the traditional boundary at 10,000 BP. This more or less rules out calibration of ${ }^{14} \mathrm{C}$ results with the published tree ring records, so all ${ }^{14} \mathrm{C}$ dates have been recalculated from the original Conventional Radiocarbon Age data using a second order polynomial. The equation is Calibrated Age $=1.40(\mathrm{CRA})-6.83 \times 10^{-6}(\mathrm{CRA})^{2}-1969$, described in Gillespie (1998) as a compromise between coral and magnetic data. This calibration adds a maximum adjustment of 4000 years at $30,000 \mathrm{BP}$, decreasing to 3000 years at 40,000 BP and 1000 years at 50,000 BP. Calibration becomes increasingly uncertain with age but this curve is compatible with the comprehensive data in Yokoyama et al (2000). Calibrated ${ }^{14} \mathrm{C}$ dates provide the best available numbers for direct comparison with "absolute" dates from other methods expressed in calendar years (where 1000 years = $1 \mathrm{ka}$ ).

Figure 2 shows histograms of ${ }^{14} \mathrm{C}$ dates from selected archaeological sites or regions to give an idea of the continental spread of Pleistocene ${ }^{14} \mathrm{C}$ dates. This diagram simply records the number of finite calibrated ${ }^{14} \mathrm{C}$ dates in each 1000 year interval, giving all results equal value and ignoring the error terms. The dashed line at $40 \mathrm{ka}$ approximates the ${ }^{14} \mathrm{C}$ "event horizon" for Australian laboratories around 1970, and the shaded region represents LGM.

1. Tasmania. A compilation of dates from three sites, Fraser Cave (Kiernan et al. 1983), Bluff Cave, and ORS7 (Cosgrove 1989) are shown; all samples were charcoal given standard acid/ alkali/acid pretreatment. The ${ }^{14} \mathrm{C}$ record shows occupation back to $34 \mathrm{ka}$, the youngest starting date for any of the regions considered here.

2. New Ireland. Again three sites are combined: Matenkupkum, Balof 2, and Panakiwuk (Allen et al. 1988; Allen 1989). The group of 5 oldest dates are on marine shell from one midden layer in the Matenkupkum cave site, where a steeply sloping shelf and tectonic processes have left the site 15 meters above present sea level. Other dates are on shell, bone or charcoal and all shell 


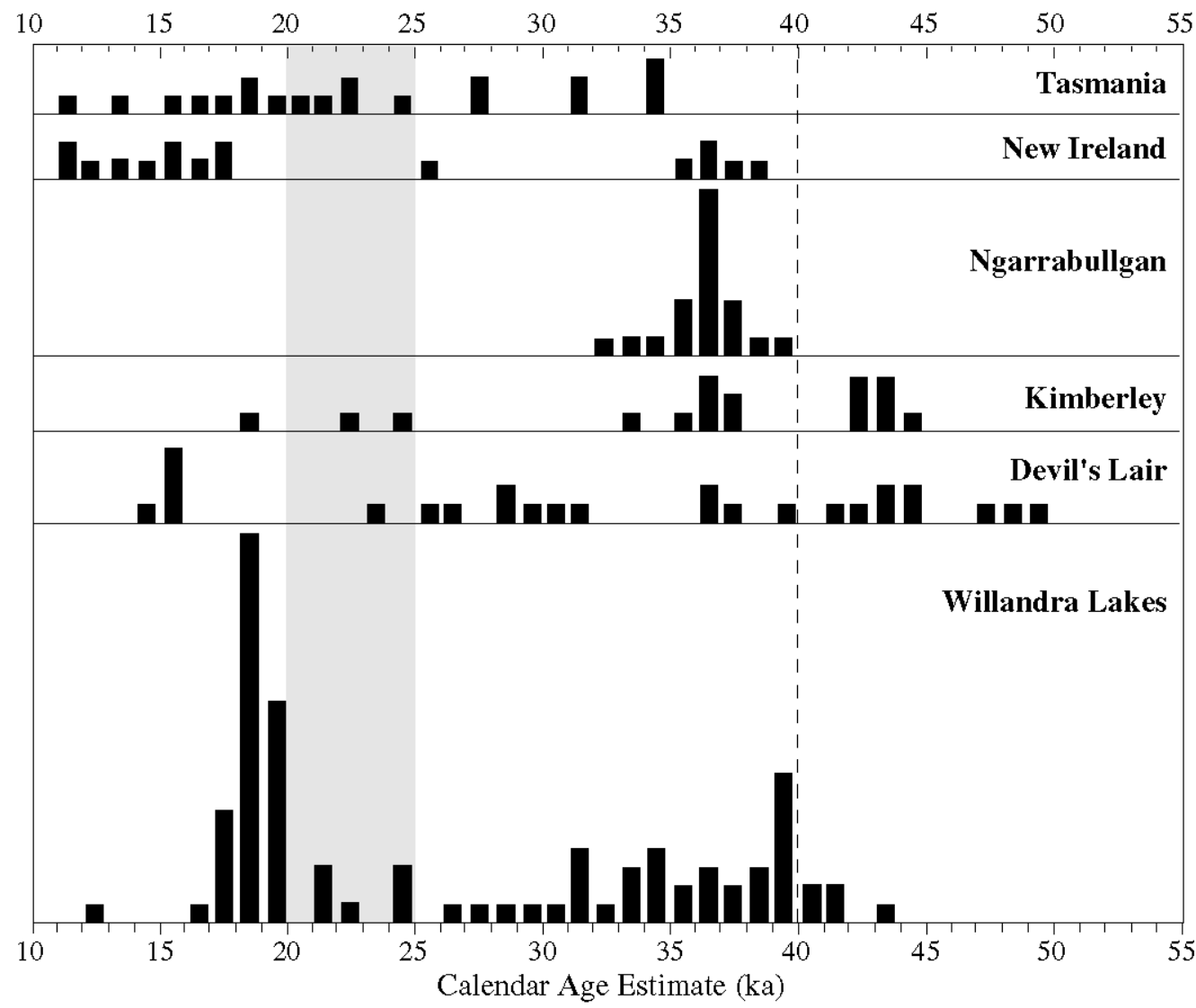

Figure 2 Calibrated ${ }^{14} \mathrm{C}$ dates from selected Sahul archaeological sites, displayed as the number of results in each 1000-year interval (references in text).

dates have been corrected for a marine reservoir effect of 400 years. New Ireland was separated from Sahul by deep water throughout the Late Pleistocene, apparently no barrier to occupation by $36 \pm 2 \mathrm{ka}$. This is only slightly younger than about $40 \mathrm{ka}$ for archaeology on the Huon Peninsula, New Guinea, suggested by U/Th dating of coral terraces and TL dating of a tephra sequence, (Groube et al. 1986).

3. Ngarrabullgan. A cave site about $100 \mathrm{~km}$ west of Cairns in north Queensland, situated on a table-top mountain 200-400 meters above surrounding plains and hills. This dry site has few mammals to disturb the deposits, with good preservation of charcoal and organic residues on stone tools. Results from AMS dating of 18 separate fragments of charcoal from a single occupation layer show a Gaussian distribution about $36 \pm 2 \mathrm{ka}$, confirmed by OSL dates of $35 \mathrm{ka}$ from the base of the same layer (David et al. 1997; Bird et al. 1999). An undated unit with sparse artifacts immediately underlying this charcoal-rich layer may represent leakage from above, not necessarily older occupation.

4. Kimberley. This region of northwestern Australia has been considered one of the likely entry points for early settlers in Sahul, via the present island of Timor. Excavations in a limestone shelter at Carpenter's Gap (O'Connor 1995; McConnell and O'Connor 1997) revealed about 1 meter of occupation sediments containing well-preserved macro plant remains: seeds, glumes 
and stem fragments of grasses, and seeds of edible fruit. Similarly, test excavations in a limestone cave site at Riwi (Balme 2000) yielded cultural deposits with well-preserved organic remains. The fairly consistent sequence of ${ }^{14} \mathrm{C}$ dates from both sites using radiometric and AMS methods has a maximum age of $44 \mathrm{ka}$. Shell dates approximately $35 \mathrm{ka}$ have recently been obtained (O'Connor et al. 2002) from the Lene Hara archaeological site on Timor.

5. Devil's Lair. This cave site in southwestern Australia was first excavated in the 1970s, yielding a stratified sequence more than 4 meters deep with ${ }^{14} \mathrm{C}$ dates on charcoal extending to $38 \mathrm{ka}$ (Dortch and Merrilees 1973; Dortch 1979; Dortch and Dortch 1996). Subsequent resampling for ${ }^{14} \mathrm{C}$, OSL and ESR dating has extended occupation of the cave to around $48 \mathrm{ka}$ (Layer 30, Turney et al. 2001). Sparse artifacts in Layers 32-38 are slightly older, with good agreement between ${ }^{14} \mathrm{C}$ and OSL in Layer 39 below the archaeology at $50 \mathrm{ka}$. ESR measurements (early uptake model) on teeth from an extant marsupial are in agreement with this sequence to $44 \mathrm{ka}$, but yield older dates than other methods on samples from Layer 39.

6. Willandra Lakes. Mungo is one of the icons of Australian archaeology; Lake Mungo is one of a series of large lakes formerly part of the Murray-Darling river system that drains a large fraction of eastern Australia. These Willandra lakes are now permanently dry, but during the Late Pleistocene they contained large quantities of fresh water which attracted some of the earliest residents. A National Park and World Heritage Area is centred on Lake Mungo, reflecting the wealth of archaeology and environmental history.

Large-scale archaeological excavations were carried out in the early 1970s near the south end of the Mungo lunette, penetrating more than 2 meters to sterile sands (Mulvaney 1974; Shawcross and Kaye 1980; Shawcross 1998). ${ }^{14} \mathrm{C}$ and TL dating results from the Willandra lakes have been recently reviewed (Bowler 1998; Bowler and Price 1998; Gillespie 1998). TL dating of heated sediments from under, and heat retainers within, hearths in the Mungo lunette overlap with calibrated ${ }^{14} \mathrm{C}$ dates on charcoal from the same fireplaces in the range $34 \pm 3 \mathrm{ka}$ (Barbetti and Polach 1973; Huxtable and Aitken 1977; Bell 1991). This period of human occupation coincides with deposition of Arumpo Unit sediments although the hearths are dug into older units. The oldest ${ }^{14} \mathrm{C}$ dates on charcoal, emu eggshell, lacustrine shell, and fish otolith at $40 \pm 3 \mathrm{ka}$ are from locations close to a transition zone in the lunettes, where clay-rich sediments derived from the lake floor during times of lower, fluctuating water levels (Upper Mungo Unit) overly quartz dominant sediments from a high lake level phase (Lower Mungo Unit). TL dates on unheated sediments are widely scattered and not consistent with the ${ }^{14} \mathrm{C}$ record (Oyston 1996; Bowler and Price 1998). Ongoing new work suggests that the Upper Mungo occupation horizons are close to $44 \mathrm{ka}$ (Spooner et al. forthcoming).

\section{Dating the Human Bones}

Although human skeletal remains have been found in many other Sahul locations, only material recovered from the Willandra Lakes region is considered. The first of more than 100 separate burials was found by Jim Bowler during geomorphic fieldwork at Lake Mungo in 1968. It is somewhat ironic that Mungo is one of the least suitable lakes for detailed reconstruction of this rich prehistory. A large fraction of the archaeological sites, mostly hearths or other fireplaces and shell middens, are found in the lunettes developed by aeolian processes on the eastern margins of the lakes. The Mungo lunette is most strongly eroded, possibly because this lake was only filled by fluctuating overflow from Lake Leaghur to the immediate north. Whatever the mechanism, large areas of the Mungo lunette have lost several meters of sediment, exposing the human bones but also rendering much of the stratigraphy horizontal. The "Walls of China" mobile white dune downwind of the Mungo 
lunette was present before European settlement and sheep grazing has accelerated erosion over the past 150 years.

Burial Mungo 1 (or WLH-1), yielded dates of $28 \mathrm{ka}$ on an acid insoluble residue and $22 \mathrm{ka}$ on "apatite" (Bowler et al. 1972). Later work showed that $>90 \%$ of the carbon in this burnt bone was alkalisoluble humic acids dated at $29 \mathrm{ka}$, with an $\mathrm{A} / \mathrm{B} / \mathrm{A}$ insoluble residue at $20 \mathrm{ka}$. Burnt bone burials near Lake Garnpung (WLH-23, 24 and 122) also yielded abundant humic acids several millennia older than the A/B/A insoluble residues dated at 13-14 ka (Gillespie 1997). The established Willandra chronology was questioned by a recent study on unburnt bone from the Mungo 3 skeleton (a.k.a. WLH-3 or LM3), with U/Th and ESR dates in the range 50-78 ka and a combined estimate of $62 \pm 6 \mathrm{ka}$ (Simpson and Grün 1998; Thorne et al. 1999). OSL dates at $61 \pm 2 \mathrm{ka}$ were obtained from sediments underlying the burial horizon, supporting the younger end of the U/Th/ESR range (these sands must be older than the burial). These results have been criticized on stratigraphic and technical grounds (Bowler and Magee 2000; Gillespie and Roberts 2000). No ${ }^{14} \mathrm{C}$ dates have been reported for the Mungo 3 skeleton, nor on any archaeological material associated with the burial, and the response of Grün et al. (2000) has not resolved all the issues.

As an added complication, previously unpublished results on several more human bones are presented in Tables 1 and 2 (Keith Fifield and Tie-Mei Chen, personal communication). AMS ${ }^{14} \mathrm{C}$ measurements and alpha spectrometry U/Th measurements were made on samples of post-cranial bone fragments in 1988-90, using procedures described in Fifield et al. (1992) or Chen and Yuan (1988). Samples from burials WLH-15 and WLH-55 were chosen because only those 2 from 56 unburnt skeletons analyzed contained $>0.2 \%$ nitrogen (Webb 1989). These proved to have well-preserved collagen, from which a total amino acids fraction was prepared by standard methods (Gillespie et al. 1986), yielding post-bomb Modern and Late Holocene dates. Burnt bone from burial WLH-28 was given standard room temperature $\mathrm{A} / \mathrm{B} / \mathrm{A}$ pretreatment chemistry to produce both humic acids $(12 \mathrm{ka})$ and insoluble residue (14 ka) dates. Direct comparison between ${ }^{14} \mathrm{C}$ and U/Th methods on WLH-55

Table $1{ }^{14} \mathrm{C}$ measurements on Willandra Lakes human bone samples ${ }^{\mathrm{a}}$

\begin{tabular}{lllc}
\hline Burial & Lab nr & Fraction dated & ${ }^{14} \mathrm{C}$ age BP \\
\hline WLH-55 & ANUA-36 & Collagen amino acids & $4000 \pm 1000$ \\
WLH-15 & ANUA-35 & Collagen amino acids & $117 \pm 5.0 \% \mathrm{M}$ \\
WLH-28 & ANUA-33 & A/B/A residue & $12,000 \pm 1000$ \\
& ANUA-34 & Humic acids & $9000 \pm 1000$ \\
\hline
\end{tabular}

${ }^{a}$ AMS ${ }^{14} \mathrm{C}$ age estimates (Keith Fifield personal communication 1990) determined on post-cranial fragments of human bone burials from the Willandra Lakes, described in Webb (1989).

Table 2 U/Th series measurements on Willandra Lakes human bones ${ }^{\mathrm{a}}$

\begin{tabular}{lllllc}
\hline Burial & Lab nr & $\mathrm{U}(\mathrm{ppm})$ & ${ }^{234} \mathrm{U} /{ }^{238} \mathrm{U}$ & ${ }^{230} \mathrm{Th} /{ }^{234} \mathrm{U}$ & ${ }^{230} \mathrm{Th}$ age (ka) \\
\hline WLH-55 & BKY 88034 & $2.62 \pm 0.14$ & $1.30 \pm 0.09$ & $0.055 \pm 0.013$ & $6.2 \pm 0.2$ \\
& & $1.39 \pm 0.17$ & & $0.225 \pm 0.062$ & $28.4 \pm 9.2$ \\
WLH-18 & BKY 88032 & $4.5 \pm 0.2$ & $1.12 \pm 0.06$ & $0.171 \pm 0.014$ & $20.3 \pm 1.8$ \\
WLH-52 & BKY 88033 & $3.65 \pm 0.22$ & $1.36 \pm 0.10$ & $0.714 \pm 0.048$ & $125 \pm 15$ \\
& & $3.65 \pm 0.22$ & $1.35 \pm 0.10$ & $0.690 \pm 0.048$ & $118 \pm 14$ \\
\hline
\end{tabular}

${ }^{a}$ Alpha spectrometry U/Th age estimates (Tie-Mei Chen personal communication 1989) determined on post-cranial fragments of human bone burials from the Willandra Lakes, described in Webb (1989). 
produced equivocal results, with very different U/Th age estimates from two separate fragments. A Holocene age was expected because of the unusually well-preserved collagen, which is supported by the younger U/Th date; the older age of 28 ka may be explained by recent leaching of uranium from the bone. A $20 \mathrm{ka}$ date for WLH-18 is unexceptional, but the U/Th estimate of $125 \mathrm{ka}$ for burial WLH-52 is at least twice the age of any archaeological site in Sahul.

\section{Additional Sites Where New OSL Methods Have Been Important}

Development of new techniques in optically stimulated luminescence dating has given additional information on some sites where ${ }^{14} \mathrm{C}$ or TL dating is equivocal: sediments with no suitable carbonaceous material and/or the true age is beyond the practical ${ }^{14} \mathrm{C}$ range, and unheated sediments where TL fails to yield stratigraphically consistent results.

1. Jinmium. The sandstone rock shelter site of Jinmium in northwestern Australia came to notoriety with TL dates suggesting pecked cupules on buried rocks were older than $58 \mathrm{ka}$, ochre at 75-116 ka, with stone artifacts and first occupation at 116-176 ka (Fullagar et al. 1996). These results were widely disbelieved, with criticism on dating and sedimentological grounds (e.g. Roberts 1997; Spooner 1998). Subsequent resampling for OSL and AMS ${ }^{14} \mathrm{C}$ dating has radically reduced the maximum age for the deposits. Small samples of charcoal from the cultural layers treated with either $\mathrm{A} / \mathrm{B} / \mathrm{A}$ or strong oxidation chemistry yielded ${ }^{14} \mathrm{C}$ dates in the range 80-3870 BP; OSL dates agree with the ${ }^{14} \mathrm{C}$ where direct comparisons were made and suggest that the all the cultural deposits are Holocene (Roberts et al. 1998a; 1999). AMS ${ }^{14} \mathrm{C}$ dating of oxalate carbon from rock varnish also suggests that the pecked cupule artwork is most probably of Holocene age (Watchman et al. 2000). In this example the TL dating of unheated sediments has been shown to yield incorrect age estimates, whereas OSL methods are likely to be correct because they measure a signal that is known to be rapidly reset by exposure to sunlight.

2. Nullabor Plains. Koonalda Cave is part of a large underground karst system developed in Eocene limestone, with water-deposited sediments on the cave floor containing hearths ${ }^{14} \mathrm{C}$ dated in the range 16-27 ka (Wright 1971). Subsequent resampling has confirmed dates for the deepest charcoal, but OSL results are considered unacceptable because a surface sample yielded an age estimate of $9.2 \pm 1.1 \mathrm{ka}$ (Roberts et al. 1996). The presence of significant disequilibrium in the radionuclide decay chains suggests that leaching (which may not have been constant) has taken place; geomorphic, ${ }^{137} \mathrm{Cs}$, and ${ }^{210} \mathrm{~Pb}$ excess data support an age of less than 100 years for the surface deposits. These analyses demonstrate that luminescence methods are unsuitable for deep cave sites where episodic storage and transport in darkness result in overestimation of the time since last exposure to sunlight.

Allen's Cave is a small rock shelter in a shallow collapsed sinkhole developed in Miocene limestone, with hearth charcoal dated to a maximum of $20 \mathrm{ka}$ (Martin 1973). Subsequent resampling yielded a near modern OSL age at the surface, good agreement between ${ }^{14} \mathrm{C}$, TL, and OSL dates at 10-11 ka and extended the occupation sequence to about $40 \mathrm{ka}$ (Roberts et al. 1996). The first application of single-aliquot and single-grain OSL measurements to archaeological sediments in Australia (Murray and Roberts 1997), demonstrated that single-aliquot estimates were consistent with traditional multiple-aliquot TL and OSL results, and that single-grain OSL measurements allow further refinement in sediments where the TL/OSL signal was incompletely reset during deposition.

3. Puritjarra. The sandstone rock shelter at Puritjarra, in the Cleland Hills west of Alic Springs, provided the first evidence that people lived in the arid central Australian region during the Late Pleistocene (Smith 1987). First occupation was estimated at about $35 \mathrm{ka}$ from TL dating, but there was an offset between the ${ }^{14} \mathrm{C}$ and TL chronologies (Smith et al. 1997). This anomaly has 
now been resolved using ABOX pretreatment chemistry on charcoal samples (Smith et al. 2001).

4. Malakunanja II and Nauwalabila I. These two sites in the wet tropical "Top End" of northern Australia were first excavated as part of an archaeological survey (Kamminga and Allen 1973) instrumental in the 1979 establishment of Kakadu National Park. ${ }^{14} \mathrm{C}$ dates on charcoal from these rock shelter sites extended to approximately $23 \mathrm{ka}$; subsequent resampling has confirmed dates for these cultural deposits with TL/OSL results similar to ${ }^{14} \mathrm{C}$ dates in the $15-30$ ka range. Below these occupation layers charcoal is very scarce to absent, but consistent TL and OSL dates suggest that artifacts in levels dated to 50-60 ka represent earlier occupation (Roberts et al. 1990a, 1994, 1998b). There has been strong archaeological criticism of this luminescence chronology (Allen 1989; Bowdler 1990; Hiscock 1990; Allen 1994; Allen and Holdaway 1995; O'Connell and Allen 1998); some of the unresolved issues are addressed in the discussion below.

\section{People and Megafauna}

Several Australian sites have been promoted as demonstrating a significant overlap of human occupation with extinct megafauna, usually on the basis of ${ }^{14} \mathrm{C}$ dates on bones or charcoal from sediments in which they are found. These results are by no means universally accepted and many dates have been rejected (Baynes 1995) on criteria proposed by Meltzer and Mead (1985), the two sites discussed illustrate some of the difficulties in dating and interpretation.

1. Lancefield Swamp. In Figure 3, the upper panel shows ${ }^{14} \mathrm{C}$ and other dates from Lancefield Swamp, a spring site in southeastern Australia with abundant megafauna and sparse archaeology. The megafaunal remains occur in a discrete bone bed 1.5-1.7 $\mathrm{m}$ below present surface, underlain by a channel fill from which charcoal was dated to about $30 \mathrm{ka}$ (Gillespie et al. 1978). Bones and teeth are very poorly preserved, with extensive mineral replacement (sometimes retaining the fibrous texture of dentine or collagen) but containing little or no residual protein; ${ }^{14} \mathrm{C}$ dates on bone fractions are widely scattered and unreliable. This poor bone preservation is in sharp contrast with other organic materials within the site: there is some charcoal, well-preserved unburnt macro plant debris and pollen throughout the sequence, plant roots below the bone bed were post-bomb modern. Recent studies using AAR and ESR methods on extinct marsupial teeth from Lancefield Swamp yielded age estimates in the range 38-60 ka (van Huet et al. 1998), significantly older than the original charcoal dates would suggest for the archaeology.

2. Cuddie Springs. The lower panel of Figure 3 shows ${ }^{14} \mathrm{C}$ charcoal dates from Cuddie Springs, an ephemeral lake/swamp site with megafauna and archaeology (Dodson et al. 1993; Furby et al. 1993; Fullagar and Field 1997; Field and Boles 1998). Megafaunal remains are found throughout a $>13 \mathrm{~m}$ sequence, including near-surface locations also containing modern cow bones. Of most interest are Stratigraphic Units $6 \mathrm{a}$ and $6 \mathrm{~b}$ at $1.0-1.7 \mathrm{~m}$ below present surface, containing extant and extinct fauna, charcoal and stone artifacts in fine-grained sediments. ${ }^{14} \mathrm{C}$ results on charcoal show a random age/depth distribution with a range of about 32-37 ka, supported by an OSL date of around $35 \mathrm{ka}$ in the same deposits (Field and Dodson 1999). There are also well-preserved organic residues on stone tools, pollen, unburnt macro plant debris, and fragments of freshwater shell, but no dates on these materials have been reported. Bones and teeth are extensively degraded with no residual protein, and in common with Lancefield Swamp the extinct megafauna skeletal remains are not articulated. 


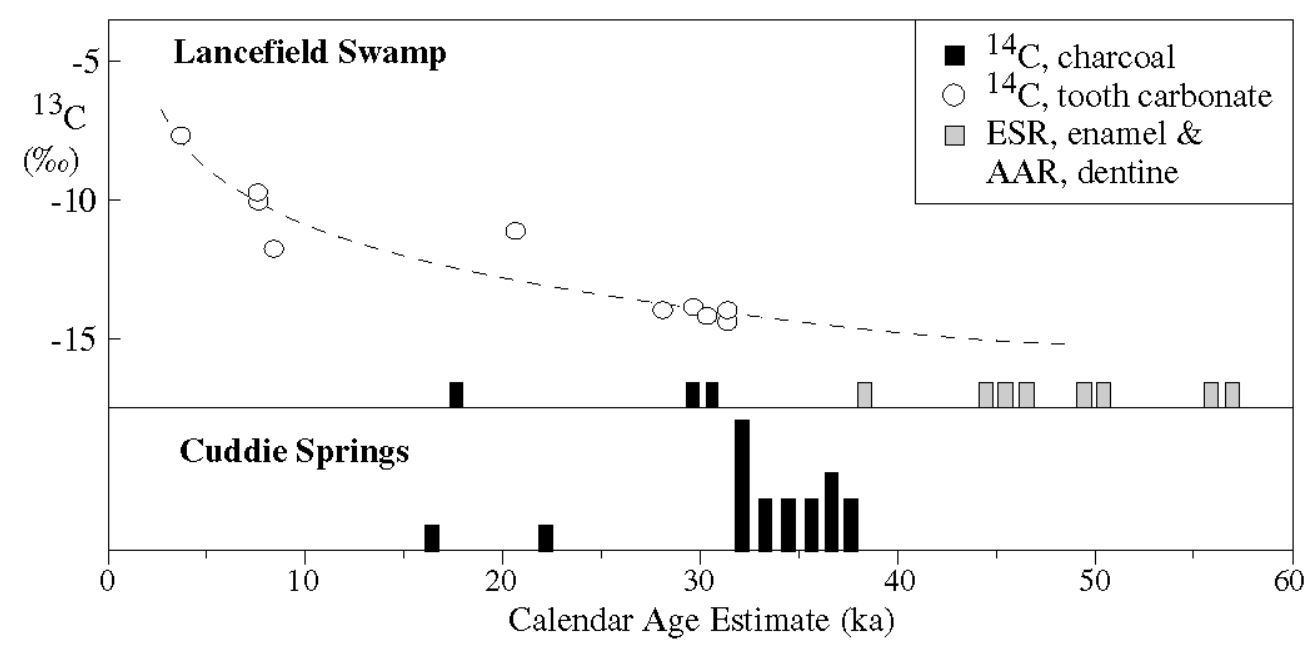

Figure $3{ }^{14} \mathrm{C}$ and other dates from selected megafauna sites. Lancefield Swamp data from Gillespie et al. (1978) and van Huet et al. (1998); Cuddie Springs data from Field and Dodson (1999), Fifield et al. (2001), and Roberts et al. (2001).

\section{DISCUSSION}

Archaeological criticism of ${ }^{14} \mathrm{C}$ and luminescence chronologies for the first occupation of Australia (e.g. Allen and Holdaway 1995; O'Connell and Allen 1998) appears to be based on concern that: the ${ }^{14} \mathrm{C}$ chronology extends only to about $40,000 \mathrm{BP}$, some TL/OSL dates are older than any ${ }^{14} \mathrm{C}$ results, $\mathrm{U} / \mathrm{Th} / \mathrm{ESR}$ dates for the Mungo 3 skeleton at $>60 \mathrm{ka}$ are older still, and Sahul dates $>50 \mathrm{ka}$ are earlier than ${ }^{14} \mathrm{C}$ dates from Europe and therefore a major revision of world prehistory is required to accommodate them.

Figure 4A shows histograms of calibrated ${ }^{14} \mathrm{C}$ dates $>35 \mathrm{ka}$ from Australia ( $\mathrm{n}=82$, this work) and from Europe ( $\mathrm{n}=131$ modern and $\mathrm{n}=76$ Neanderthal, Bocquet-Appel and Demars 2000). Under the Allen and coworkers interpretation, this would imply that modern humans arrived in Australia at the same time as both modern humans and extinct Neanderthal arrived in Europe, possibly about $50 \mathrm{ka}$. Similarly, the distributions in Figure 4B would imply that modern Australians, who were certainly eating the extant fish, shellfish, and emu, could also have been eating the extinct Genyornis $(\mathrm{n}=22$, Miller et al. 1999) over this time range.

These are clearly not realistic interpretations because we know, for example, that the representative extinct megafauna were present in Europe and Australia much earlier than $50 \mathrm{ka}$. Chappell et al. (1996a) pointed out that such distributions are simply reflecting the limitations of ${ }^{14} \mathrm{C}$ dating, including contributions from chemical decontamination, analytical background and calibration. The fact that older ${ }^{14} \mathrm{C}$ dates exist for geological samples is irrelevant because sufficient carbon in uncontaminated form is rare in the oldest archaeological sites. Over the three decades of ${ }^{14} \mathrm{C}$ dating results from Europe and Australia shown in Figure 4A, chemistry has improved and analytical background reduced from about $1 \%$ to $0.1 \%$, resulting in a change of the applicable "event horizon" from about $40 \mathrm{ka}$ to $50 \mathrm{ka}$. Similar technological advances have also been made in other dating methods, but incorrect dates have not been removed from the distributions. 


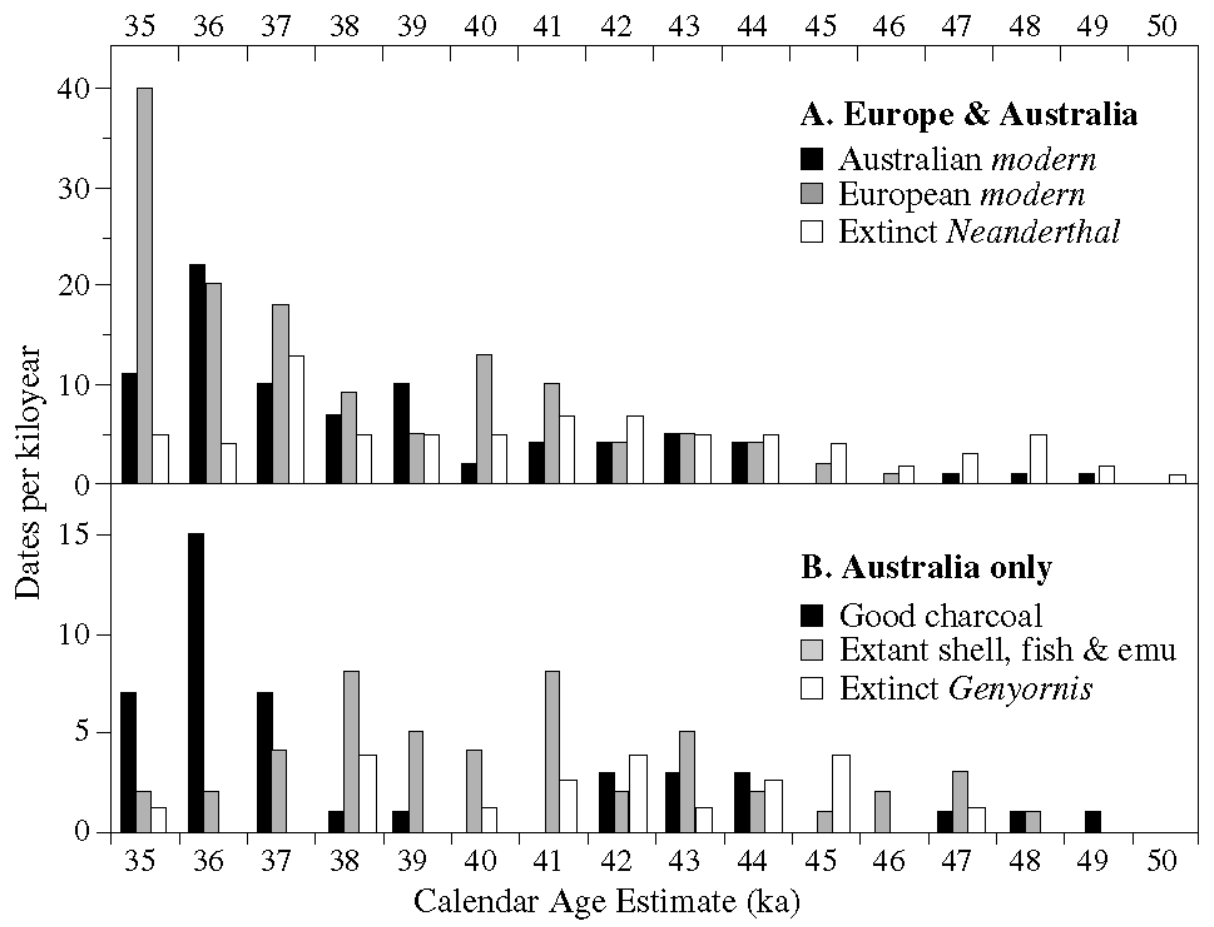

Figure 4 A: Distribution of calibrated ${ }^{14} \mathrm{C}$ dates from Australian and European archaeology. Australian data from Figure 2 (references in text); European data from Bocquet-Appel and Demars (2000). B: Distribution of calibrated ${ }^{14} \mathrm{C}$ dates on different sample materials. Data from Figure 2 and Miller et al. (1999).

\section{(A) Filtering the ${ }^{14} \mathrm{C}$ Dataset}

Many black samples labeled "charcoal" from Australian archaeological sites turn out to contain almost no real charcoal; all fractions have similar carbon content and might more descriptively be labeled unburnt detritus or "compost" (Gillespie 1998). Shell middens in the Willandra Lakes are usually found in black, compost-rich sediments with alkali-soluble fractions frequently older than $\mathrm{A} / \mathrm{B} / \mathrm{A}$ residues, but it is not clear from what source this carbon is derived. Wet oxidation pretreatment methods can remove compost without destroying real charcoal (Gillespie 1990, 1997; Bird and Grocke 1997; Bird et al. 1999; Turney et al. 2001; Fifield et al. 2001). With these observations in mind, ${ }^{14} \mathrm{C}$ measurements on Australian black samples may be loosely divided into 3 phases:

Phase 1 -minimal chemistry with a ${ }^{14} \mathrm{C}$ "event horizon" near $38-40,000$ BP (e.g. Polach et al. 1970; Gillespie and Temple 1973).

Phase 2-improved A/B/A chemistry with a ${ }^{14} \mathrm{C}$ "event horizon" of 42-44,000 BP (most post-1980 work).

Phase 3-ABOX-SC chemistry with a ${ }^{14} \mathrm{C}$ "event horizon" of 48-50,000 BP (Bird et al. 1999; Fifield et al. 2001; Turney et al. 2001).

In the most recent Phase 3 work, ABOX-SC refers to acid/base/dichromate oxidation followed by a 3-temperature stepped combustion, which adds reassurance that the chemistry has been successful because unburnt organics will combust at a lower temperature than charcoal. Some idea of the magnitude of contamination and/or analytical background limitations for charcoal samples from the Devil's Lair site is shown in Table 3. For samples near the lowest occupation horizon (Layers 27-28) 
the Phase 1 dates are about 15,000 years younger than overlapping Phase 3, OSL and ESR dates around $44 \mathrm{ka}$, with Phase 2 dates close to the Phase 3 results. Below all the archaeology (Layer 39), Phase 1 and 2 dates are 8-10,000 years younger than Phase 3 and OSL dates of approximately 50 ka from the same layer, but the ESR dates are 13-24,000 years older.

Table 3 Magnitude of contamination and background limitations at Devil's Lair ${ }^{\mathrm{a}}$

\begin{tabular}{|c|c|c|}
\hline Method & Layers $27-28$ & Layer 39 \\
\hline Phase 1 & $\begin{array}{l}24,600 \pm 800 \text { BP }(\text { SUA-31 }) \\
27,700 \pm 700 \text { BP (SUA-539) }\end{array}$ & $37,750 \pm 2500 \mathrm{BP}($ SUA-698) \\
\hline Phase 2 & $\begin{array}{l}38,800 \pm 1750 \mathrm{BP}(\mathrm{OZD}-327) \\
40,500 \pm 1750 \mathrm{BP}(\mathrm{OZD}-330) \\
41,500 \pm 2000 \mathrm{BP}(\mathrm{OZD}-329)\end{array}$ & $40,400 \pm 1900 \mathrm{BP}(\mathrm{OZD}-331)$ \\
\hline Phase 3 & $\begin{array}{l}41,460 \pm 1300 \mathrm{BP}(\text { ANUA-11709) } \\
\quad(44.3 \pm 2.6 \mathrm{ka})\end{array}$ & $\begin{array}{l}48,130 \pm 2300 \mathrm{BP}(\mathrm{ANUA}-11511) \\
(49.6 \pm 4.6 \mathrm{ka})\end{array}$ \\
\hline OSL & $\begin{array}{l}43.4 \pm 2.2 \mathrm{ka}(\mathrm{DL} 8) \\
44.4 \pm 2.1 \mathrm{ka}(\mathrm{DL} 7)\end{array}$ & $51.1 \pm 2.6 \mathrm{ka}(\mathrm{DL} 17)$ \\
\hline $\mathrm{ESR}(\mathrm{EU})$ & $\begin{array}{l}42 \pm 3 \mathrm{ka}(\# 1437 \mathrm{~B}) \\
44 \pm 3 \mathrm{ka}(\# 1437 \mathrm{~A})\end{array}$ & $\begin{array}{l}64 \pm 7 \mathrm{ka}(\# 1448 \mathrm{~B}) \\
75 \pm 7 \mathrm{ka}(\# 1448 \mathrm{~A})\end{array}$ \\
\hline
\end{tabular}

${ }^{\mathrm{a} O S L}$, ESR, and ${ }^{14} \mathrm{C}$ data from Gillespie and Temple (1973), Dortch (1979), and Turney et al. (2001). Layers $27-$ 28 are close to the lowest occupation levels, Layer 39 is below the deepest artifacts.

Similar comparisons using ABOX-SC procedures in the Kimberley sites (Carpenter's Gap and Riwi) and in the Willandra Lakes suggest the oldest occupation horizons are 43-44 ka (Fifield et al. 2001; Spooner et al. forthcoming). The numerous Willandra Lakes ${ }^{14} \mathrm{C}$ carbonate dates on shells, emu eggshells and fish otoliths with Phase 1 or 2 results near 36,000 BP (40 ka) would now also appear to be 3000-4000 years too young on the same criteria. Support for this interpretation comes from paired ${ }^{14} \mathrm{C}$ and TIMS U/Th results with extended leaching experiments on Huon Peninsula coral carbonate (Yokoyama et al. 2000), suggesting that carbonate contamination may account for $3000-4000$ years of the age differences found.

Thus both charcoal and carbonate samples are subject to contamination and often give incorrect results in the $>30,000$ BP period, even when the dates are clearly resolved from the "event horizon". Removing the dubious organics, shell, otolith and eggshell dates from the Australian dataset in Figures 2 and 4A leaves the charcoal results shown in Figure $4 \mathrm{~B}$ as the most reliable ${ }^{14} \mathrm{C}$ evidence for human occupation. These 44 "good" charcoals are all finite age estimates younger than $50 \mathrm{ka}$ and well supported by some combination of TL, OSL, U/Th, and ESR dating.

\section{(B) The Bone Dates}

The direct ${ }^{14} \mathrm{C}$ dating of bone has had a troubled history, in most cases because the samples fail to meet one of the original assumptions for the method: "the possibility of obtaining unaltered samples" (Arnold and Libby 1949). Poor organic preservation in most Willandra human bones is similar to bones from other semi-arid open sites in Australia or elsewhere. Well-documented methods for reliable ${ }^{14} \mathrm{C}$ measurements on single amino acids from bone collagen (e.g. Stafford et al. 1991) have not been applicable because almost no protein has been found. Phase 1 or 2 chemistry has so far produced no results older than about $28 \mathrm{ka}$ for the Mungo 1 cremation, with a younger group of burials at 13-14 ka near Lake Garnpung (WLH-23, 24 and 122; Gillespie 1997). 
There are additional problems for U/Th/ESR methods because the mineral components as well as the organics have been altered by diagenesis. The movement of isotopes into and out of bones and sediments is complicated by changing hydrology and the commonly applied Early or Linear Uptake models do not necessarily cover all possibilities (e.g. Hedges and Millard, 1995; Millard and Pike 1999). For the WLH-50 burial around 14 ka, TIMS and gamma spectrometry U/Th dates overlap convincingly (Simpson and Grün 1998), but there is just as much variability in the individual U/Th/ ESR results on the Mungo 3 skeleton (Thorne et al. 1999) as in the Upper Mungo occupation ${ }^{14} \mathrm{C}$ results. It is worth repeating that these human burials were originally dug into sediments older than the occupation surface of the day, which may also have been deflated prior to burial. Samples for OSL dating of sediments underlying the Mungo 3 skeleton were taken several hundred meters from the burial site and may not be relevant to the skeleton's precise position (Bowler and Magee 2000; Grün et al. 2000). While there is no doubt that some Lower Mungo sediments deeper than the burial are $60 \mathrm{ka}$, this is a maximum possible age and places no limit on how much later the burial pit was actually dug into the lunette. Similar remarks apply to the U/Th results on WLH-52 in Table 3, where there is no environmental information available and the apparent age corresponds to deposits underlying the Lower Mungo: the Golgol Unit (96-126 ka) in which no cultural material has been found (Bowler 1998; Bowler and Price 1998). The considerable uncertainty about the true age of all the Willandra skeletons suggest that none of the dates should be accepted at face value.

Some of the conclusions drawn from a DNA study (Adcock et al. 2001) of Mungo 3 and several other Willandra Lakes and Kow Swamp human burials depend on their true age. Table 1 includes ${ }^{14} \mathrm{C}$ dates for WLH-15 (modern) and WLH-55 (late Holocene) for which DNA extraction has been reported. A reanalysis of the genetic data suggests that Mungo 3 and the other skeletons all fit within modern human variability (Cooper et al. 2001), so judgement should probably be withheld until both the dating and the DNA analysis have been replicated. Whether the Mungo 3 remains turn out to be 40,50 , or $60 \mathrm{ka}$ does not seem to matter for the human origins debate, with modern people living in Africa $>100$ ka there is plenty of time to reach Europe or Australia by any of those dates.

\section{(C) The Luminescence Results}

In the Arnhem Land sites Malakunanja II and Nauwalabila I, there is compost but very little charcoal throughout the sequences studied so ${ }^{14} \mathrm{C}$ has limited value. The main point of divergence between commentators concerns the luminescence results suggesting that there was human occupation 50$60 \mathrm{ka}$. Applying the same kind of analysis to the Malakunanja II data, there is reasonable agreement between Phase $2{ }^{14} \mathrm{C}$ and multiple-aliquot TL dates near modern at the surface of a Holocene shell midden, and between Phase 2 or $3{ }^{14} \mathrm{C}$ and TL dates of 15-25 ka in occupation deposits approximately $1.5-2.2 \mathrm{~m}$ below surface. Very consistent multiple-aliquot TL, single-aliquot OSL and single-grain OSL dates around 44 ka overly a pit containing artifacts, with sediments at the lowest artifact level about $2.5 \mathrm{~m}$ deep dated by TL/OSL at approximately $60 \mathrm{ka}$, but single-grain OSL dates group near $55 \mathrm{ka}$ (Roberts et al. 1998b). Similarly, at Nauwalabila I there is an OSL date near modern at the surface and reasonable agreement between Phase $2{ }^{14} \mathrm{C}$, TL, and OSL dates in cultural levels 1.1-1.8 m below surface at 13-30 ka. Deeper sediments have little or no charcoal, with artifacts in sediments at 2.3-3.0 m bracketed by 53-60 ka OSL dates (Roberts et al.1994). The TL/OSL methods applied to these sites are the same as those showing such good cross-dating results at, for example, Devil's Lair (Turney et al. 2001).

\section{(D) The Megafauna}

An alternative presentation of the AMS data from Lancefield Swamp is given at the top of Figure 3, showing the change in carbonate $\delta^{13} \mathrm{C}$ and ${ }^{14} \mathrm{C}$ age with increasing acetic acid extraction time on 
megafaunal teeth, reaching a plateau for "apatite carbonate" with $\delta^{13} \mathrm{C}=-14 \%$ after about 90 hours. The cluster of results near $30 \mathrm{ka}$ is the same age as charcoal from channel fill underlying the bone bed. A fitted logarithmic curve suggests recent "exogenous carbonate" diffusing into the teeth, trending toward an equilibrium isotopic composition between modern and fossil carbonate. This interpretation supports the idea that high-energy fluvial transport deposited gravels containing the bones and charcoal at that time (van Huet et al. 1998), and also reset the carbon isotopes in megafaunal teeth. Extrapolating the diffusion curve implies a true age for the megafauna older than that represented by the charcoal, perhaps similar to (or greater than) the ESR and AAR estimates.

Direct AAR dating was also attempted on marsupial teeth from Cuddie Springs, but few amino acids were found and $\mathrm{D} / \mathrm{L}$ ratios widely scattered (Clarke 1999). The ${ }^{14} \mathrm{C}$ and OSL ages imply that both charcoal and sand were deposited at the same time, but neither is necessarily dating the megafauna or the stone tools. No hearth structures have been reported, suggesting that the charcoal came from somewhere else, and the nearest source of stone is $4 \mathrm{~km}$ from the site. David (2001) points out that seed grinding tools from Cuddie Springs are assigned the same $35 \mathrm{ka}$ age as the charcoal and sand, whereas examples from most other Sahul sites are of Holocene age, and suggests that European well-digging and other operations may be partly responsible for some disturbance of the deposits. Single-grain OSL measurements (Roberts et al. 2001) also suggest that there has been disturbance at the site because sediments throughout the sequence contain quartz grains with different optical ages, with the maximum age in Stratigraphic Unit 6 identical to the multi-aliquot OSL result.

Roberts et al. (2001) studied 28 megafaunal sites using OSL dating of quartz in sediments containing the bones (or attached to bones in museum specimens), and TIMS U/Th dating of flowstones in cave deposits bracketing the most recent occurrence of megafauna. Only sites with articulated skeletal remains in undisturbed deposits were used to estimate an extinction time of $46 \mathrm{ka}$ (95\% confidence interval 39.8-51.2 ka) for the flightless bird Genyornis and several genera of large marsupials and reptiles. This accords well with the estimate of $50 \pm 5 \mathrm{ka}$ for extinction of Genyornis determined using TIMS U/Th on eggshell and OSL on sediments containing eggshell reported by Miller et al. (1999). These results all predate human occupation at Cuddie Springs and do not support the contention that extinct megafauna survived until Last Glacial Maximum (Field and Boles 1998). In terms of organic preservation, bone taphonomy and stone tool distribution, both Lancefield Swamp and Cuddie Springs might be described as "disharmonious assemblages" containing components with different true ages.

\section{(E) Do the Outliers Fit?}

Removing some of the dross from all distributions yields the dataset shown in Figure 5, where ${ }^{14} \mathrm{C}$ dates are arranged in decreasing order and dates from other methods in increasing order. This diagram illustrates the right tail of a distribution of good archaeological charcoal dates $>40$ ka from Devil's Lair, Carpenter's Gap, Riwi, and Mungo, but the left tails of distributions for archaeological TL/OSL and U/Th/ESR dates (Devil's Lair, Malakunanja, Nauwalabila, and Mungo), and nonarchaeological TL/OSL and U/Th dates on megafauna from diverse sites throughout the continent. Convergence of these overlapping distributions can be seen at 44-46 ka, with a divergence near 60 ka represented only by TL/OSL dates from Malakunanja and Nauwalabila plus the combined U/ Th/ESR date on Mungo 3.

The isotopic and other measurements made on skeletal remains and sediments are not the issue here, debate is about whether or not the outliers are compatible with other work in the region. For the bone dates there is not enough supporting geochemical evidence, and even with high resolution measurements the problems are not necessarily resolvable for degraded material from disturbed locations. 


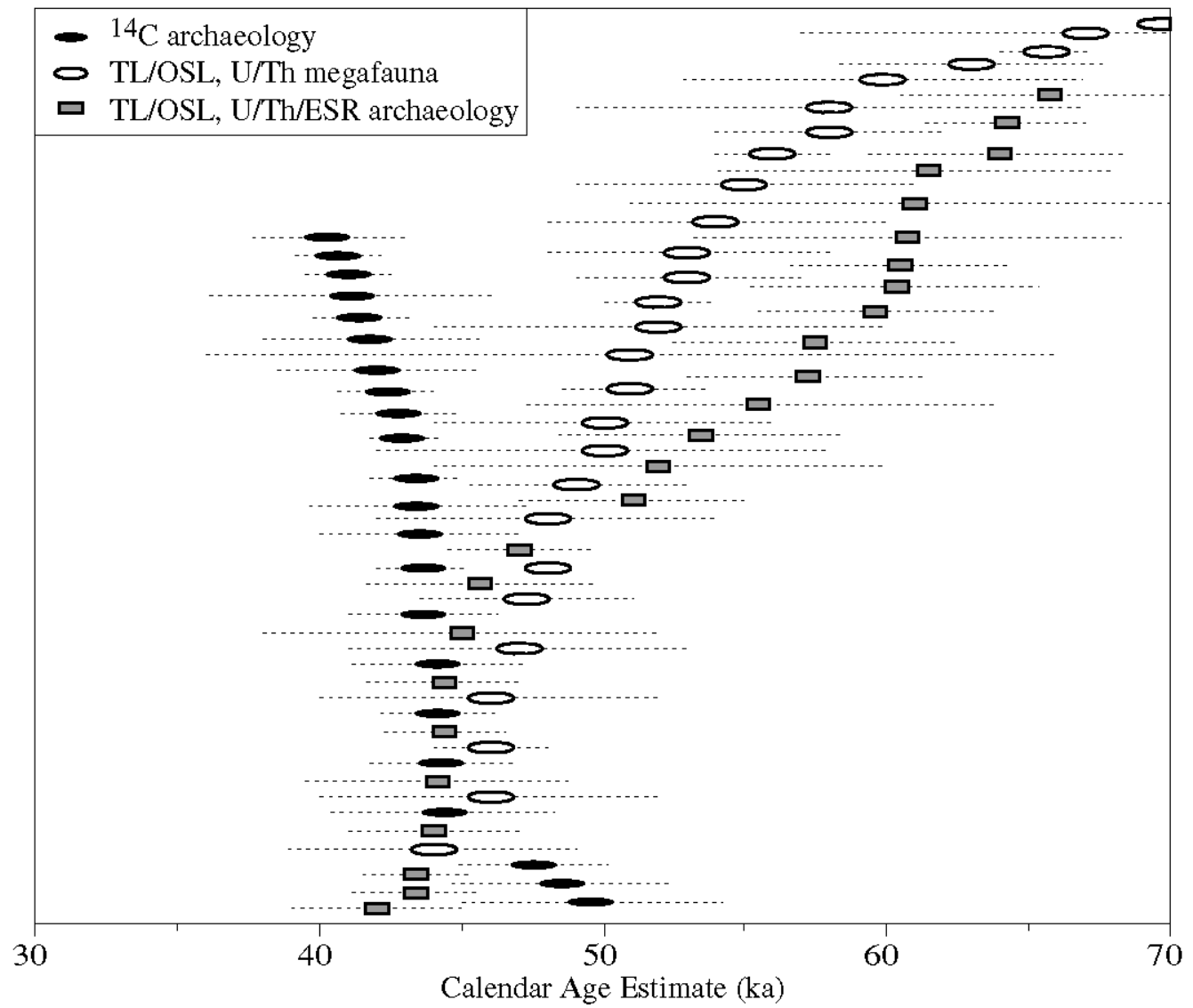

Figure 5 Distribution of Australian archaeology and extinct megafauna results. Black ovals are calibrated ${ }^{14} \mathrm{C}$ dates from archaeological sites at Devil's Lair, Carpenter's Gap, Riwi, and Mungo; gray squares are archaeological TL/OSL and U/Th/ESR dates from Devil's Lair, Malakunanja II, Nauwalabila I, and Mungo; white ovals are TL/OSL dates from diverse megafauna sites and U/Th dates on Genyornis eggshell. Data from Miller et al. (1999), Thorne et al. (1999), Fifield et al. (2000), Roberts et al. (1994, 1998b, 2001), Turney et al. (2001), and Spooner et al. (forthcoming).

The stratigraphic situation at several of these sites is similar in the sense that artifacts are found below (but not too far below) definite cultural horizons, so it is not possible to rule out leakage from younger deposits. Artifacts in sediments deeper than 44 ka occupation at Devil's Lair are still $<50 \mathrm{ka}$, artifacts at Malakunanja are within reach of $44 \mathrm{ka}$ occupation, artifacts in Mungo sediments deeper than probable 44 ka occupation are undated, and the Mungo 3 burial could have been inserted from $44 \mathrm{ka}$ cultural levels. Nauwalabila is then the only survivor with artifacts possibly $>50 \mathrm{ka}$. Good scientific evidence confirming occupation of Sahul older than this may still eventuate from one of these sites (and more sites will surely be found) but age estimates and stratigraphic associations in this period require more than standard analysis.

These issues have a certain resonance with the establishment of pre-Clovis occupation and with Late Pleistocene megafaunal extinction in the Americas (e.g. Haynes 1969; Martin 1986; Meltzer et al. 1997). In the American debates a shift of only about 1000 years near $14 \mathrm{ka}$ is involved, which should be well within reliable dating range for most numerical methods, but environmental circumstances often thwart both the best of intentions and available technology. The Australian debates are even 
less tractable, because the total number of reliable dates in the 40-70 ka range is small and standard errors too large to resolve some of the questions. There is very little reliable evidence for any of the extinct Australian megafauna surviving later than $46 \pm 4 \mathrm{ka}$, overlapping the earliest multi-dated human cultural deposits at $45 \pm 3 \mathrm{ka}$, which could be interpreted as supporting the global "blitzkrieg hypothesis" for megafaunal extinction proposed by Martin (1984).

\section{CONCLUSIONS}

Dating the first Australians has become an issue for which ${ }^{14} \mathrm{C}$ may no longer be the final word, because we are near a reliable age limit for the method. The "event horizon" with best available technology is about $50 \mathrm{ka}$, with realistically large error ranges reflecting uncertainty in both measurement and calibration of ${ }^{14} \mathrm{C}$ dates. Other dating methods such as OSL, ESR, AAR, and U/Th extend the available age range, sometimes by an order of magnitude, and there is increasingly good agreement between methods within the ${ }^{14} \mathrm{C}$ limits. Direct bone dating remains a difficult problem throughout the Late Pleistocene, and significant technical developments have been required in all dating techniques to push back the time of first human occupation from the very uncertain $>37,800$ BP of thirty years ago.

There are currently four widely separated regions of Australia with human occupation layers dated at $45 \pm 3$ ka by some combination of overlapping ${ }^{14} \mathrm{C}$, TL, OSL, and ESR results: Devil's Lair in the southwest, Carpenter's Gap and Riwi in the northwest, Malakunanja in the north, and Mungo in the southeast. According to the most recent TL, OSL, and U/Th results, many species of megafauna from all climatic zones became extinct at about the same time as people spread across the continent. Age resolution is not yet good enough in this period to precisely define when the first boat people arrived or the last big animal died, and the possible existence of older archaeology or younger megafauna will require further archaeological and stratigraphic confirmation.

\section{ACKNOWLEDGMENTS}

Although I have been involved with the ${ }^{14} \mathrm{C}$ dating of samples from several of the sites mentioned here, most of the work discussed is not mine and the interpretation presented is a personal one reflecting bias from my background as a ${ }^{14} \mathrm{C}$ chemist. This view does not always agree with those published by excavators or dating scientists. Particular thanks to Michael Bird, Tie-Mei Chen, Keith Fifield, Bert Roberts, Nigel Spooner, and Matthew Spriggs for generously making available unpublished results; and to Jim Bowler, John Chappell, Charlie Dortch, Judith Field, John Magee, Paul Martin, Peter White, and many others for stimulating discussions.

\section{REFERENCES}

Adcock GJ, Dennis ES, Easteal S, Huttley GA, Jermilin LS, Peacock WJ and Thorne A. 2001. Mitochondrial DNA sequences in ancient Australians: implications for modern human origins. Proceedings of the $\mathrm{Na}$ tional Academy of Science 98:537-42.

Allen J. 1989. When did humans first colonize Australia? Search 20:149-54

Allen J. 1994. Radiocarbon determinations, luminescence dating and Australian archaeology. Antiquity 68:339-43.

Allen J, Holdaway S. 1995. The contamination of Pleistocene radiocarbon determinations in Australia. Antiquity 69:101-12.
Allen J, Gosden C, Jones R, White JP. 1988. Pleistocene dates for the human occupation of New Ireland, northern Melanesia. Nature 331:707-9.

Arnold JR, Libby WF. 1949. Age determinations by radiocarbon content: checks with samples of known age. Science 110:678-80.

Barbetti M, Polach HA. 1973. ANU radiocarbon datelist V. Radiocarbon 15(2):241-51.

Balme J. 2000. Excavations revealing 40,000 years of occupation at Mimbi Caves in south central Kimberley of Western Australia. Australian Archaeology 51:1-5.

Baynes A. 1999. The question "Why did the Australian Pleistocene megafauna become extinct" currently is 
unanswerable because there are no reliable dates for any of the species. In: Baynes A, Long JA, editors. Papers in vertebrate palaeontology. Perth: Records of the Western Australian Museum. Supplement 57. p 391.

Bell WT. 1991. Thermoluminescence dates for the Lake Mungo Aboriginal fireplaces and the implications for radiocarbon dating. Archaeometry 33:43-50.

Bird MI, Grocke DR. 1997. Determination of the abundance and carbon isotope composition of burnt carbon in sediments. Geochimica Cosmochimica Acta 61: 3413-23.

Bird MI, Ayliffe LK, Fifield LK, Cresswell R, Turney CSM, Barrows TT and David B. 1999. Radiocarbon dating of 'old' charcoal using a wet oxidation-stepped combustion procedure. Radiocarbon 41(1):127-40.

Bocquet-Appel J-P and Demars P-Y. 2000. Population Kinetics in the Upper Palaeolithic in Western Europe. Journal of Archaeological Science 27:551-70.

Bowdler S. 1990. 50,000 year old site in Australia - is it really that old? Australian Archaeology 31:93.

Bowler JM. 1998. Willandra Lakes revisited: environmental framework for human occupation. Archaeology in Oceania 33:120-55.

Bowler JM, Magee JW. 2000. Redating Australia's oldest skeleton: a sceptic's view. Journal of Human Evolution 38:719-26.

Bowler JM, Price DM. 1998. Luminescence dates and stratigraphic analyses at Lake Mungo: review and new perspectives. Archaeology in Oceania 33:156-68.

Bowler JM, Thorne AG. 1976. Human remains from Lake Mungo: discovery and excavation of Mungo 3. In: Kirk RL, Thorne AG, editors. The origin of the Australians. Canberra: Australian Institute of Aboriginal Studies. p 127-38.

Bowler JM, Thorne AG, Polach HA. 1972. Pleistocene man in Australia: age and significance of the Mungo skeleton. Nature 240:48-50.

Bowler JM, Jones R, Allen H, Thorne AG. 1970. Pleistocene human remains from Australia: a living site and human cremation from Lake Mungo, western New South Wales. World Archaeology 2: 39-60.

Chappell J. 1991. Late Quaternary environmental changes in eastern and central Australia, and their climatic interpretation. Quaternary Science Reviews 10: 377-90.

Chappell J, Head J, Magee J. 1996a. Beyond the radiocarbon limit in Australian archaeology and Quaternary research. Antiquity 70:543-52.

Chappell J, Omura A, Esat T, McCulloch M, Pandolfi J, Ota Y, Pillans B. 1996b. Reconciliation of late Quaternary sea levels derived from coral terraces at Huon Peninsula with deep sea oxygen isotope records. Earth and Planetary Science Letters 141:227-36.

Chen T-M, Yuan S. 1988. Uranium-series dating of bones and teeth from Chinese Palaeolithic sites. Archaeometry 30:59-76.
Clarke SJ. 1999. The application of the AAR geochronological technique to Late Pleistocene fossil teeth from the Australian megafaunal locality Cuddie Springs. Unpublished BSc (Hons) thesis. Department of Geosciences, University of Wollongong.

Cooper A, Rambaut A, Macaulay V, Willerslev E, Hansen AJ, Stringer C. 2001. Science 292:1655.

Cosgrove R. 1989. Thirty thousand years of human colonization in Tasmania: new Pleistocene dates. Science 243:1706-8.

David B. 2002. Landscapes, rock-art and the dreaming: an archaeology of preunderstanding. London: Continuum Press. Chapter 8.

David B, Roberts R, Tuniz C, Jones R, Head J. 1997. New optical and radiocarbon dates from Ngarrabullgan Cave, a Pleistocene archaeological site in Australia: implications for the comparability of time clocks and for the human colonization of Australia. Antiquity 71: 183-8.

Dodson J, Fullagar R, Furby J, Prosser I. 1993. Humans and megafauna in a Late Pleistocene environment at Cuddie Springs, northwestern New South Wales. Archaeology in Oceania 28:93-9.

Dortch CE. 1979. 33,000 year old stone and bone artifacts from Devil's Lair, Western Australia. Records of the Western Australian Museum 7:329-67.

Dortch CE, Dortch J. 1996. Review of Devil's Lair artefact classification and radiocarbon chronology. Australian Archaeology 43:28-32.

Dortch CE, Merrilees D. 1973. Human occupation of Devil's Lair, Western Australia during the Pleistocene. Archaeology and Physical Anthropology in Oceania 8:89-115.

Field J, Boles WE. 1998. Genyornis newtoni and Dromaius novaehollandiae at 30,000 BP in central northern New South Wales. Alcheringa 22:177-88.

Field J, Dodson J. 1999. Late Pleistocene megafauna and archaeology from Cuddie Springs, southeastern Australia. Proceedings of the Prehistoric Society 65:275301.

Fifield K, Allen GL, Ophel TR, Head J. 1992. Accelerator mass spectrometry of ${ }^{14} \mathrm{C}$ at the Australian National University. Radiocarbon 34(3):452-7.

Fifield LK, Bird MI, Turney CSM, Hausladen PA, Santos GM and di Tada ML. 2001. Radiocarbon dating of the human occupation of Australia prior to $40 \mathrm{ka}$ BP successes and pitfalls. Radiocarbon 43(2B):1139-45.

Fullagar R, Field J. 1997. Pleistocene seed-grinding implements from the Australian arid zone. Antiquity 71: 300-7.

Fullagar RLK, Price DM, Head LM. 1996. Early human occupation of northern Australia: archaeology and thermoluminescence dating of Jinmium rock shelter, Northern Territory. Antiquity 70:751-73.

Furby JH, Fullagar R, Dodson JR, Prosser I. 1993. The Cuddie Springs bone bed revisited. In: Smith MA, Spriggs M, Fankhauser B, editors. Sahul in review: 
Pleistocene archaeology in Australia, New Guinea and Island Melanesia. Canberra: Research School of Pacific Studies, Australian National University. p 204-10.

Gillespie R. 1990. On the use of oxidation for AMS sample pretreatment. Nuclear Instruments and Methods B52:345-7.

Gillespie R. 1997. Burnt and unburnt carbon: dating charcoal and burnt bone from the Willandra Lakes, Australia. Radiocarbon 39(3):225-36.

Gillespie R. 1998. Alternative timescales: a critical review of Willandra Lakes dating. Archaeology in Oceania 33:169-82.

Gillespie R, Temple RB. 1973. Sydney University natural radiocarbon measurements II. Radiocarbon 15(3): 566-73.

Gillespie R, Horton DR, Ladd P, Macumber PM, Rich TH, Thorne AR, Wright RVS. 1978. Lancefield Swamp and the extinction of the Australian megafauna. Science 200:1044-8.

Gillespie R, Hedges REM, Humm MJ. 1986. Routine AMS dating of bone and shell proteins. Radiocarbon 28(2A):451-6.

Gillespie R, Roberts RG. 2000. On the reliability of age estimates for human remains from Lake Mungo. Journal of Human Evolution 38:727-32.

Groube L, Chappell J, Muke J, Price D. 1986. A 40,000 year old human occupation site at Huon Peninsula, Papua new Guinea. Nature 324:453-5.

Groves CP. 1996. Hovering on the brink: nearly but not quite getting to Australia. Perspectives in Human Biology 2:83-7.

Grün R, Spooner NA, Thorne A, Mortimer G, Simpson JJ, McCulloch MT, Taylor L, Curnoe D. 2000. Age of the Lake Mungo 3 skeleton, reply to Bowler and Magee and to Gillespie and Roberts. Journal of Human Evolution 38:733-41.

Haynes CV. 1969. The earliest Americans. Science 166: $709-15$.

Hedges REM, Millard AR. 1995. Bones and groundwater: towards the modelling of diagenetic processes. Journal of Archaeological Science 22:155-64.

Hiscock P. 1990. How old are the artefacts in Malakunanja II? Archaeology in Oceania 25:122-4.

Huxtable J, Aitken MJ. 1977. Thermoluminescent dating of Lake Mungo geomagnetic polarity excursion. $\mathrm{Na}$ ture 265:40-1.

Jones R. 1968. The geographical background to the arrival of man in Australia and Tasmania. Archaeology and Physical Anthropology in Oceania 3:186-215.

Kamminga J, Allen HR. 1973. Report on the archaeological survey. The Alligator Rivers fact-finding study. Darwin: Government Printer.

Kiernan K, Jones R, Ranson D. 1983. New evidence from Fraser Cave for glacial age man in southwest Tasmania. Nature 301:28-32.

McConnell K, O'Connor S. 1997. 40,000 year record of food plants in the southern Kimberley, Western Australia. Australian Archaeology 45:20-31.

Martin HA. 1973. Palynology and historical ecology of some cave excavations in the Australian Nullabor. Australian Journal of Botany 21:283-305.

Martin PS. 1984. Prehistoric overkill: the global model. In: Martin PS, Klein RG, editors. Quaternary extinctions: a prehistoric revolution. Tucson: University of Arizona Press. p 354-403.

Martin PS. 1986. Refuting Late Pleistocene extinction models. In: Eliott DK, editor. Dynamics of extinction. New York: John Wiley \& Sons. p 107-30.

Meltzer DJ, Mead JI. 1985. Dating late Pleistocene extinctions: theoretical issues, analytical bias, and substantive results. In: Meltzer DJ, Mead JI, editors. Environment and extinction: man in late glacial North America. Orono: University of Maine, Center for the Study of Early Man. p 145-73.

Meltzer DJ, Grayson DK, Ardila G, Barker AW, Dincauze DF, Haynes CV, Mena F, Nunez L, Stanford DJ. 1997. On the Pleistocene antiquity of Monte Verde, southern Chile. American Antiquity 62:659-63.

Millard AR, Pike AWG. 1999. Uranium-series dating of the Tabun neanderthal: a cautionary note. Journal of Human Evolution 36:581-5.

Miller GH, Magee JW, Johnson BJ, Fogel ML, Spooner NA, McCulloch MT, Ayliffe LK. 1999. Pleistocene extinction of Genyornis newtoni: human impact on Australian megafauna. Science 283:205-8.

Mulvaney DJ. 1974. Summary report of the first Mungo Project season. AIAS Newsletter 1:21-2.

Mulvaney DJ. 1975. The prehistory of Australia. 2nd edition. Melbourne: Penguin Books Australia.

Mulvaney DJ, Kamminga J. 1999. Prehistory of Australia. Sydney: Allen and Unwin.

Murray TA, editor. 1998. Archaeology of Aboriginal Australia: a reader. Sydney: Allen and Unwin.

Murray AS, Roberts RG. 1997. Determining the burial time of single grains of quartz using optically stimulated luminescence. Earth and Planetary Science Letters 152:163-80.

O'Connell JF, Allen J. 1998. When did humans first arrive in greater Australia and why is it important to know? Evolutionary Anthropology 6:132-46.

O'Connor S. 1995. Carpenter's Gap Rockshelter 1: 40,000 years of Aboriginal occupation in the Napier Ranges, Kimberley, WA. Australian Archaeology 40: $58-9$.

O'Connor S, Spriggs M, Veth P. 2002. Excavation at Lene Hara Cave establishes occupation in East Timor at least 30,000-35,000 years ago. Antiquity 76:45-50.

Oyston B, 1996. Thermoluminescence age determinations for the Mungo 3 human burial, southeastern Australia. Quaternary Science Reviews (Quaternary Geochronology) 15:739-49.

Polach HA, Lovering JF, Bowler JM. 1970. ANU radiocarbon datelist IV. Radiocarbon 12(1):1-18. 
Roberts RG. 1997. Luminescence dating in archaeology: from origins to optical. Radiation Measurements 27: 819-92.

Roberts RG, Jones R. 2000. Chronologies of carbon and silica: evidence concerning the dating of the earliest human presence in northern Australia. In: Tobias PV, Moggie-Cecchi J, Raas MA, Doyle GA, editors. $\mathrm{Hu}$ manity from African naissence to coming millenia, colloquia in human biology and palaeoanthropology. Firenze: University Press. p 239-48.

Roberts RG, Jones R, Smith MA. 1990a. Thermoluminescence dating of a 50,000-year-old human occupation site in northern Australia. Nature 345:153-6.

Roberts RG, Jones R, Smith MA. 1990b. Stratigraphy and statistics at Malakunanja II: reply to Hiscock. Archaeology in Oceania 25:125-9.

Roberts RG, Jones R, Spooner NA, Head MJ, Murray AS, Smith MA. 1994. The human colonization of Australia: optical dates of 53,000 and 60,000 years bracket human arrival at Deaf Adder Gorge, Northern Territory. Quaternary Science Reviews 13:573-84.

Roberts RG, Spooner NA, Jones R, Cane S, Olley JM, Murray AS, Head MJ. 1996. Preliminary luminescence dates for archaeological sediments on the Nullabor Plain, South Australia. Australian Archaeology 42:7-16.

Roberts R, Bird M, Olley J, Galbraith R, Lawson E, Laslett G, Yoshida H, Jones R, Fullagar R, Jacobsen G, Hua Q. 1998a. Optical and radiocarbon dating at Jinmium rock shelter in northern Australia. Nature 393: 358.

Roberts R, Yoshida H, Galbraith R, Laslett G, Jones R, Smith M. 1998b. Single-aliquot and single-grain optical dating confirm thermoluminescence age estimates at Malakunanja II rock shelter in northern Australia. Ancient TL 16:19-24.

Roberts RG, Galbraith RF, Olley JM, Yoshida H, Laslett GM. 1999. Optical dating of single and multiple grains of quartz from Jinmium rock shelter, northern Australia: Part II, results and implications. Archaeometry 41:365-95.

Roberts RG, Flannery TF, Ayliffe LK, Yoshida H, Olley JM, Prideaux GJ, Laslett GM, Baynes A, Smith MA, Jones R, Smith BL. 2001. New ages for the last Australian megafauna: continent-wide extinction about 46,000 years ago. Science 292:1889-92.

Shackleton NJ. 2000. The 100,000 year ice-age cycle identified and found to lag temperature, carbon dioxide and orbital eccentricity. Science 289:1897-902.

Shawcross W. 1998. Archaeological excavations at $\mathrm{Mu}-$ ngo. Archaeology in Oceania 33:183-200.

Shawcross FW, Kaye M. 1980. Australian archaeology: implications of current interdisciplinary research. Interdisciplinary Science Reviews 5:112-28.

Simpson JJ, Grün R. 1998. Non-destructive gamma spectrometric U-series dating. Quaternary Science Re- views (Quaternary Geochronology) 17:1009-22.

Smith MA. 1987. Pleistocene occupation in arid central Australia. Nature 328:710-1.

Smith MA. 1998. The pattern of continental occupation: late Pleistocene colonization of Australia and New Guinea. In: Murray TA, editor. Archaeology of Aboriginal Australia: a reader. Sydney: Allen and Unwin. p 41-9.

Smith MA, Prescott JR, Head MJ. 1997. Comparison of ${ }^{14} \mathrm{C}$ and luminescence chronologies at Puritjarra rock shelter, central Australia. Quaternary Science Reviews (Quaternary Geochronology) 16:299-320.

Smith MA, Bird MI, Turney CSM, Fifield LK, Santos GM, Hausladen PA, di Tada ML. 2001. New ABOXSC AMS ${ }^{14} \mathrm{C}$ ages remove dating anomalies at Puritjarra rock shelter. Australian Archaeology 53:45-7.

Spooner N. 1998. Human occupation at Jinmium, northern Australia: 116,000 years ago or much less? Antiquity 71:173-8.

Spooner NA, McBryde I, Magee JW, Johnston H, Clark P, Questiaux DG, Bird M, Olley JM, Lawson L, Lawson G, Hill NG, Taylor L. Optical dating at the Lake Mungo lunette, Willandra Lakes, Australia. 2001. Optical dating at the Mungo lunette. Quaternary Science Reviews (Quaternary Geochronology). Forthcoming.

Stafford TW Jr, Hare PE, Currie L, Jull AJT, Donohue DJ. 1991. Accelerator radiocarbon dating at the molecular level. Journal of Archaeological Science 18: 35-72.

Thorne A, Grün R, Mortimer G, Spooner NA, Simpson JJ, McCulloch M, Taylor L, Curnoe D. 1999. Australia's oldest human remains: age of the Lake Mungo 3 skeleton. Journal of Human Evolution 36:591-612.

Turney CSM, Bird MI, Fifield LK, Roberts RG, Smith MA, Dortch CE, Grün R, Lawson E, Ayliffe LK, Miller GH, Dortch J, Cresswell RG. 2001. Early human occupation at Devil' Lair, southwestern Australia 50,000 years ago. Quaternary Research 55:3-13.

van Huet S, Grün R, Murray-Wallace CV, Redvers-Newton N, White JP. 1998. Age of the Lancefield megafauna: a reappraisal. Australian Archaeology 46:5-11.

Watchman AL, Tacon P, Fullagar R, Head L. 2000. Minimum ages for pecked rock markings from Jinmium, northwestern Australia. Archaeology in Oceania 35: $1-10$.

Webb SG. 1989. The Willandra Lakes hominids. Canberra: Department of Prehistory, Australian National University.

Wright RVS. 1971. The archaeology of Koonalda Cave. In: Mulvaney DJ, Golson J, editors. Aboriginal man and environment in Australia. Canberra: ANU Press. p 105-13.

Yokoyama Y, Esat T, Lambeck K, Fifield LK. 2000. Last ice age millennial scale climate changes recorded in Huon Peninsula corals. Radiocarbon 42(1):383-401. 